\title{
Peran Pengasuh dalam Manajemen Perubahan pada Lingkungan Organisasi Pondok Pesantren Tegalsari di Masa Pandemi Covid-19
}

\author{
Aqimi Dinana ${ }^{1}$, Subiyantoro ${ }^{2}$ \\ Universitas Islam Negeri Sunan Kalijaga Yogyakarta \\ aqimibelajar@gmail.com ${ }^{1}$, subiyantorodr@gmail.com ${ }^{2}$
}

\begin{abstract}
Abstrak: Pendidikan yang diatur oleh suatu lembaga membutuhkan seorang pemimpin yang memiliki standar kepemimpinan yang ideal. Seorang pemimpin dituntut untuk mampu menjadi seorang agen pembawa perubahan pada suatu lembaga yang dinaunginya. Perubahan yang dimaksud diatur dalam sebuah manajemen perubahan, sehingga dapat membawa organisasi yang dipimpinnya dapat mencapai tujuan yang ditargetkan. Pondok pesantren sebagai salah satu lembaga pendidikan Islam memiliki sosok seorang kyai atau pengasuh yang bertanggung jawab atas pondok pesantren yang dipimpinnya secara berkesinambungan. Penelitian ini merupakan jenis penelitian kualitatif yang hasilnya dijabarkan secara deskriptif. Pondok Pesantren Tegalsari dibawah asuhan KH Asyhari Abta menghadapi sebuah fenomena baru pandemi covid-19. KH Asyhari Abta memiliki sebagai pengasuh Pondok Pesantren Tegalsari memiliki peran sebagai catalyst, solution givers, process helpers, resources linkers.
\end{abstract}

Kata Kunci: manajemen perubahan; peran pengasuh; Pondok Pesantren Tegalsari.

Abstract: Education regulated by an institution requires a leader who has ideal leadership standards. A leader to be able to become an agent of change in an institution that he shelters. Changes set in a management change, so as to bring the organization he leads to achieve the targeted goals. Islamic boarding school as one of the Islamic educational institutions has a kyai or caregiver who is responsible for the boarding school he leads by delivery. This research is a type of qualitative research with descriptive results. The Tegalsari Islamic Boarding School under the care of KH Asyhari Abta is facing a new phenomenon of the COVID-19 pandemic. KH Asyhari Abta as a caregiver for the Tegalsari Islamic Boarding School has a role as a catalyst, solution givers, process helpers, resource linkers.

Keywords: change; leader; Tegalsari Islamic Boarding School.

\section{Pendahuluan}

Pemimpin merupakan faktor penentu dalam kesuksesan atau gagalnya suatu organisasi dan usaha. Kualitas pemimpin di berbagai bidang kehidupan seperti dunia bisnis, kesehatan, pendidikan, religi, perusahaan, politik, sosial, pemerintahan dan lain sebagainya akan sangat berpengaruh pada masa depan keberhasilan lembaganya. ${ }^{1}$ Hal ini disebabkan karena seorang pemimpin yang berhasil sukses adalah dia yang bisa mengelola organisasi yang dipimpinnya, mampu memberikan pengaruh kepada banyak orang secara konstruktif, memberikan contoh teladan perilaku yang benar dalam

\footnotetext{
${ }^{1}$ Rz. Fahmi Khumaini and Ricky Satria Wiranata, 'Kepemimpinan Dalam Pendidikan Islam', AlFahim, Jurnal Manajemen Pendidikan Islam, 01.2 (2019), p. hlm. 01.
} 
mencapai tujuan bersama dalam organisasi, serta semangat kerja kelompok dapat meningkat. ${ }^{2}$

Suatu masyarakat yang terdapat pola hubungan sosial di dalamnya tentu membutuhkan sosok pemimpin dalam keberlangsungannya. Tujuan bersama dibawa oleh masing-masing individu sebagai wujud pembentukan masa depan masyarakat. Islam secara serius mendorong umat agar dalam pengaturan kehidupan bermasyarakat menunjuk seorang pemimpin yang dianggap sebagai sosok yang memiliki kedalaman ilmu untuk memimpin dan memecahkan persoalan kehidupan yang ada di masyarakat. ${ }^{3}$ Kehidupan masyarakat dengan kehadiran seorang pemimpin merupakan sebuah kepastian. Kehidupan bermasyarakat umat Islam didorong untuk untuk memunculkan sosok pemimpin yang mampu amanah berdasarkan kesepakatan masyarakat. ${ }^{4}$

Perubahan merupakan suatu hal yang selalu menyertai setiap keberlangsungan sebuah lembaga maupun perseorangan. Perjalanan seseorang maupun sebuah lembaga tidak dapat terlepas dari kesiapannya dalam menghadapi anomali yang ada. Perubahan terjadi tentu saja tergantung dari pembawaan individu yang menginginkan sebuah perubahan. Roda dunia terus berputar secara dinamis, tidak ada kehidupan yang berlangsung statis. Pendidikan pun demikian, mengalami berbagai macam rodanya. Perputaran pendidikan tentu saja tidak terlepas dari kebutuhan masyarakat sebagai pelaku pendidikan. Fenomena yang ada di sekitar lembaga pendidikan baik dari segi lingkungan, sosial, budaya, bencana, wabah, pandemi, mendorong lembaga pendidikan untuk terus mengalami perubahan. Perubahan yang terjadi di lembaga pendidikan secara signifikan terus mengalami peningkatan.

Pada era masa kini, apabila lembaga pendidikan tidak dapat memberikan perubahan yang meningkat tentu saja lembaga pendidikan tersebut akan hilang ditelan zaman. Kebutuhan akan pendidikan pada masa kini tentu tidak dapat dibandingkan dengan kebutuhan pendidikan pada zaman penjajahan. Akan sangat berbeda jauh tujuan pendidikan yang ingin dicapai pada tiap masa. Oleh karenanya, sekolah sebagai lembaga pendidikan haruslah dapat mengikuti arus dengan membawa perubahan ke arah yang positif.

Perubahan pada lembaga pendidikan memerlukan pengelola manajemen agar perubahan yang ada dapat terarah. Peran pemimpin, dalam hal ini Pengasuh di lembaga pendidikan Islam Pondok Pesantren menjadi sangat penting. Hal ini dilandaskan dari tugas utama Pengasuh Pondok Pesantren sebagai pemangku kebijakan tertinggi tentu saja akan menjadi titik utama perubahan dalam lembaga pendidikan yang dipimpinnya. Pengasuh Pondok Pesantren lah yang akan menjadi arah penentu kebijakan Pondok Pesantren dan menjadi gawang manajemen perubahan.

Dalam penelitian ini akan dibahas bagaimana manajemen perubahan di Pondok Pesantren Tegalsari yang barada di Desa Wedomartani, Kecamatan Ngemplak, Kabupaten Sleman, Daerah Istimewa Yogyakarta (DIY). Serta mengulas bagaimana peran Pengasuh Pondok Pesantren Tegalsari dalam manajemen perubahan di tengah Pandemi Covid-19? Data diperoleh dengan melakukan observasi atau pengamatan langsung yaitu di Pondok Pesantren Tegalsari, di mana data hasil pengamatan dielaborasi

\footnotetext{
${ }^{2}$ Abdul Wahab, Umiarso, Kepemimpinan Pendidikan dan Kecerdasan Spiritual, (Yogyakarta: ArRuzz Media, 2011), hlm 73.

${ }^{3}$ Ahmad Ibrahim Abu Sinn, Manajemen Syariah, (Jakarta: PT RajaGrafindo Persada, 2012), hlm. 127.

${ }^{4}$ M. Ma'ruf Abdullah, Manajemen Berbasis Syariah, (Yogyakarta: Aswaja Pressindo, 2012), hlm 83.
} 
dengan diskursus atau teori manajemen yang penulis ambil dari beberapa literatur mengenai manajemen.

\section{Pembahasan}

Manajemen perubahan tersusun atas dua kata, yakni: manajemen dan perubahan. Rue \& Byars mendefinisikan manajemen secara terminologi sebagai "management is a form of work actvities involves coordinating an organizaton's and capial-toward acomplishing organizational objectives". 5 Manajemen merupakan sebuah perwujudan kerjasama dalam melakukan suatu kegiatan melalui koordinasi organisasi dan modal dalam mengupayakan tujuan organisasi. Definisi yang dijabarkan oleh Rue \& Byars tersebut dapat ditarik kesimpulan, manajemen adalah sebuah proses koordinasi organisasi dan modal dalam rangka mencapai tujuan.

Daft mengungkapkan "Management is attainment of organizational goals in an effective and efficient manner throught planning, organizing, leading, and controlling organizational resources. "6 Manajemen memiliki arti sebagai proses tercapainya tujuantujuan organisasi dengan cara yang efektif dan efisien melalui perencanaan, pengorganisasian, kepemimpinan, dan pengendalian sumber daya organisasi. Manajemen menurut Daft tersebut memandang makna manajemen dari fungsinya.

R. Terry memiliki pendapat yang sama dengan Daft yang mengartikan manajemen berdasarkan fungsi manajemen yaitu "management is a distinct process consisting of planning, organizing, actuating, and controlling performed to determine and accomplish stated objectives by the use human being and other resources." "7 Manajemen mengandung makna sebagai suatu proses unik yang tersusun atas tindakan-tindakan penyusunan rencana, pengorganisasian, pelaksanaan dan pengendalian yang dilaksanakan dalam rangka menentukan serta mencapai sasaran-sasaran yang telah dirumuskan melalui pemanfaatan sumber daya yang ada.

Berdasarkan beberapa arti manajemen yang diungkapkan oleh beberapa tokoh, dapat ditarik kesimpulan bahwa manajemen adalah sebuah proses yang unik terdiri dari penyusunan rencana, pengorganisasian, pelaksanaan dan pengendalian yang dilaksanakan oleh pengurus organisasi melalui pemberdayaan sumber daya manusia dan sumber daya lainnya bertujuan untuk mencapai tujuan/ sasaran bersama yang telah dirumuskan secara efektif dan efisien.

Mengacu kepada pengertian manajemen di atas, maka menjadi terang bahwa organisasi yang berorientasi pendidikan Islam, dalam hal ini Pondok Pesantren Tegalsari pada prinsipnya memakai prinsip-prinsip manajemen yang meliputi proses perencanaan, pengorganisasian, penggerakkan, dan pengendalian dengan memberdayakan sumber daya manusia dan sumber daya lainnya.

Dalam proses perencanaan, Pondok Pesantren Tegalsari memiliki perencanaan umum yakni yang terangkum dalam visi Pondok Pesantren. Pondok Pesantren Tegalsari sebagai Pondok Pesantren Mahasiswa bervisi mencetak intelektual Islam yang berfaham Ahlussunnah Wal Jama'ah annahdliyyah. Selanjutnya pengorganisasian dilakukan dengan membentuk struktur kepengurusan. Pengasuh Pondok Pesantren berada di struktur tertinggi yang mengkontrol penuh gerak organisasi Pondok Pesantren Tegalsari. Pelaksana program Pondok Pesantren dikordinatori oleh seorang Santri yang dipilih

\footnotetext{
${ }^{5}$ Rue, Leslie W. \& Byars Lloyd L. Human resources management. (Boston: Irwin, 2000), hlm. 4

${ }^{6}$ Daft, R. L. Management (2 nd .ed). (Orlando: The Dryden Press a Division of holt Rinehart and Winston, Inc, 1991), hlm. 5

${ }^{7}$ Amirullah dan Rindyah Hanafi, Pengantar Manajemen. (Malang: Graha Ilmu, 2002), hlm. 4
} 
secara musyawarah maupun yang ditunjuk langsung oleh Pengasuh Pondok Pesantren. Kordinator tersebut mempunyai nama lain yaitu Lurah Pondok.

Sebagaimana kita ketahui, mulai dari bulan Februari 2020 hingga saat ini, dunia sedang dilanda wabah Covid-19, Indonesia tentu terdampak. Seluruh pola kehidupan mengalami perubahan dan memaksa adanya penyesuaian-penyesuaian tak terkecuali perubahan dan penyesuaian pola pendidikan Islam di Pondok Pesantren Tegalsari. Terkait hal ini akan dibahas mengenai bagaimana perubahan dan penyesuaian tersebut dilakukan di Pondok Pesantren Tegalsari.

Perubahan yang terbentuk atas kata dasar ubah memiliki arti berganti atau menjadi lain. Kata ubah dibubuhi kata tambahan menjadi perubahan dan memiliki arti sebagai suatu keadaan yang berubah, pertukaran, peralihan. Perubahan bermakna sebuah proses penggeseran atau penggantian suatu kondisi ke dalam kondisi lain atau munculnya sebuah perbedaan sesuatu yang berasal dari kondisi sebelumnya yang dinyakatakan dengan kehadiran usaha ke arah yang lebih baik. Perubahan disini tertuju pada suatu kondisi yang telah berbeda pada dimensi waktu yang terbaru.

Covid-19 merupakan wabah virus menular. Watak virus yang menyerang dan menular ini memaksa meminimalisir bahkan meniadakan aktifitas manusia bertatap muka dan kontak langsung. Menjaga jarak merupakan salah satu cara menghentikan penyebaran virus. Hal ini tentu merupakan kondisi baru yang berbeda, yang menjadi faktor lembaga seperti Pondok Pesantren harus melakukan perubahan. Bentuk perubahan aktifitas organisasi Pondok Pesantren Tegalsari mengikuti saran protokol kesehatan dalam menghadapi bencana wabah yang banyak disosialisasikan dalam bentuk informasi yang terakses.

Perubahan dalam paradigma organisasi didefinisikan sebagai suatu pergerakan yang berasal dari masa sekarang menuju ke masa yang akan datang pada konsidi yang diinginkan. Perubahan yang berada di masa sekatang tersebut dipandang dari sudut proses, struktur, budaya, dan manusia. ${ }^{8}$ Sekat pembatas rumusan perubahan ini berwujud pada struktur organisasi, orang, budaya, dan proses organisasi. Makna lain perubahan adalah proses menjalankan hal baru dengan langkah yang baru, mengikuti jalan yang baru, memanfaatkan teknologi terbarukan, mengadopsi sistem baru, menjalankan prosedur manajemen terbaru, merger (penggabungan), menjalankan penataan ulang organisasi, atau kejadian yang memiliki sifat mengganggu dengan sangat signifikan. Rumusan perubahan ini mengandung makna bahwa perubahan organisasi dapat terjadi di berbagai aspek kehidupan organisasi, termasuk pula pada sekolah sebagai sebuah organisasi pendidikan.

Berdasarkan beberapa pemaknaan manajemen dan perubahan di atas, maka dapat dirumuskan definisi manajemen perubahan. Manajemen perubahan menurut Wibowo adalah sebuah proses yang berjalan dengan sistematis dalam upaya pemberdayaan seluruh pengetahuan, sumber daya, dan sarana yang diperlukan guna memberikan pengaruh perubahan pada subjek yang menjadi sasaran dari proses perubahan. ${ }^{10}$ Kementerian Tenaga Kerja dan Transmigrasi mengungkap manajemen perubahan sejalan dengan pendapat Wibowo, yakni sebuah proses terstruktur melibatkan seluruh pengetahuan, sumber daya dan sarana yang dibutuhkan oleh organisasi guna bergerak dari situasi sekarang ke situasi akan datang yang diharapkan, yaitu tujuan kinerja yang

\footnotetext{
${ }^{8}$ Potts, Rebecca and La Marsh, Jeanne, Managing for Success, (London: Duncan Baird Publishers, 2004), hlm 36

${ }^{9}$ Davidson, Jeff, Change Management, The Complete Ideal's Duides, (Jakarta: Prenada, 2005), hlm. 3

${ }^{10}$ Wibowo, Managing Change, Pengantar Manajemen Perubahan, Pemahaman Tentang Mengelola Perubahan dalam Manajemen, (Bandung: ALFABETA, 2006), hlm. 37
} 
lebih baik dan guna pengelolaan personal terdampak dari proses perubahan dapat teratasi. $^{11}$

Berdasar berbagai macam pemaknaan istilah manajemen perubahan dalam paradigma organisasi, maka dapat ditarik kesimpulan bahwa manajemen perubahan adalah sebuah proses yang terstruktur mulai dari pembuatan rencana, pengorganisasian, pelaksanaan, hingga pengendalian yang dijalankan oleh pengurus organisasi guna mewujudkan pergeseran situasi dari masa sekarang ke situasi yang diinginkan di masa yang akan datang, dengan melibatkan sumber daya organisasi untuk mewujudkan tujuan yang telah dirancang bersama secara efektif dan efisien. Dengan kata lain, manajemen perubahan adalah sebuah langkah yang dijalankan suatu organisasi untuk beralih dari kondisi yang sebelumnya (the before condition) menuju ke kondisi yang setelahnya (the after condition), dengan harapan kondisi setelahnya lebih baik dari sebelumnya. Berubahanya kondisi yang sebelumnya menjadi kondisi setelahnya tersebut akan sangat memungkinkan melakukan perubahan budaya organisasi sehingga hasil dari perubahan pada kondisi yang lebih baik itu merupakan hasil kesepakatan bersama dari komponen organisasi.

\section{Manajemen Perubahan di Pondok Pesantren Tegalsari}

Manajemen perubahan adalah sebuah proses yang terstruktur mulai dari penyusunan rencana, pengorganisasian, pelaksanaan hingga pengendalian yang dilaksanakan oleh pengurus organisasi untuk menuju keadaan yang diharapkan di masa yang akan datang. Pandemi covid-19 yang terjadi secara masif menjalar ke seluruh pelosok negeri tentu mendorong adanya manajemen perubahan dalam tiap organisasi yang terdampak pandemi. Tujuannya jelas agar organisasi mampu bertahan dalam situasi pandemi sekarang dan tetap berkembang pada masa yang akan datang.

Telah sedikit disinggung bahwa Pandemi Covid-19 ini telah mengubah kebiasaankebiasaan organisasi yang sebelumnya bisa dilakukan dengan pola normal ke pola-pola baru. Begitu pula dengan Manajemen Pondok Pesantren Tegalsari. Manajemen perubahan harus dirancang agar organisasi tetap bisa efektif mencapai visi awal Pondok Pesantren. Mengatur kamar santri hingga mengatur pola pengajian dengan menjaga jarak merupakan beberapa hal yang dijalankan dalam aktifitas Pondok Pesantren.

Untuk sekadar memperkaya wawasan pembaca terkait isu manajemen, selanjutnya penulis akan menyajikan pembahasan mengenai Konsep Manajemen Perubahan sebagai referensi atau landasan bagi pemangku kebijakan khususnya yang terkait penyelenggara Pendidikan Islam.

\section{Konsep Manajemen Perubahan}

Kurt Lewin (1951) mengusulkan sebuah teori force field theory, yang menjelaskan bahwa situasi suatu peristiwa merupakan equilibrium (keseimbangan) dari dua sumber energi yang berlawanan, yaitu energi yang mendorong adanya perubahan (driving forces) dan energi yang menegakkan keberadaan (status kuo) yang menggagalkan terjadinya suatu perubahan (restraining forces). ${ }^{12}$ Perubahan dapat dilaksanakan dengan mendorong atau memperkuat driving force dan mendiskreditkan atau memperlemah restraining

\footnotetext{
${ }^{11}$ Kementerian Tenaga Kerja dan Transmigrasi, Konsep Rencana Strategis Manajemen Perubahan Kementerian Tenaga Kerja Dan Transmigrasi Republik Indonesia Tahun 2012, Jakarta: Kemnakertrans, 2012), hlm. 5

${ }^{12}$ Dadang Rahman Munandar, 'Manajemen Perubahan Organisasi Sekolah Luar Biasa', Jurnal Wahana Karya Ilmiah, Vol. 3, Nomor 1 (2019), p. hlm.282.
} 
force. Titik keseimbangan (equilibrium) baru harus diresmikan terlebih dahulu supaya perubahan bisa diukur dan dikendalikan.

Schermerhorn, Hunt, Osborn mengungkapkan terdapat dua macam konsep perubahan yakni; (1) konsep perubahan yang terencana (Planned Change) dan (2) konsep perubahan yang tidak terencana (Unplanned Change). ${ }^{13}$ Perubahan yang tidak terencana ini terjadi begitu saja selama berlangsungnya waktu, atau adanya faktor pendorong eksternal yang menjadi penyebab timbulnya perubahan tersebut, yang akan berpengaruh terhadap organisasi. Maka, biasanya organisasi-organisasi dan individu-individu segera bereaksi terhadap perubahan-perubahan yang tidak direncanakan tersebut, guna meminimalisir kerusakan yang terjadi, atau untuk mempertahankan atau memperbaiki situasi yang berlaku. Di lain pihak, perubahan yang direncanakan merupakan hasil dari tindakan persiapan yang dilaksanakan secara sadar, guna mencapai tujuan tertentu atau kondisi keorganisasian yang diinginkan.

Perubahan-perubahan yang direncanakan umumnya berupaya guna memperoleh dua macam tipe hasil. Adapun tipe pertama ditujukan ke arah memperbaiki kemampuan organisasi yang bersangkutan untuk menghadapi perubahan-perubahan yang tidak direncanakan, yang sedang dihadapi olehnya. Perubahan-perubahan yang terjadi dalam bidang ini, mencakup antara lain: upaya meningkatkan efektivitas pengumpulan informasi dan sistem-sistem peramalan (forecasting systems) dan fleksibilitas organisasi tersebut, demikian rupa, hingga ia dapat menyesuaikan diri dengan perubahan-perubahan tersebut secara tepat dan pada waktu yang tepat.

Tipe kedua perencanaan yang direncanakan ditujukan ke arah mengubah perilaku para anggota supaya mereka menjadi kontributor-kontributor lebih efektif, bagi tujuantujuan organisasi yang bersangkutan. Perubahan-perubahan dalam kategori ini mencakup: upaya menciptakan sikap-sikap baru, nilai-nilai baru, dan cara-cara memvisualisasi organisasi dan peranan para anggota di dalamnya maupun pemberian pelatihan guna meningkatkan produktivitas antarhubungan pribadi dan pencapaian kontribusi-kontribusi kreatif. $^{14}$

\section{Faktor-faktor yang Mendorong Perubahan}

Robert Kreitner dan Angelo Kinicki (2001) sebagai pakar perilaku individu menuliskan dalam bukunya Organizational Behavior, yang dikutip oleh Arbono Lasmahadi (2005) menjelaskan bahwa ada dua energi yang menjadi pendorong adanya keinginan untuk melaksanakan perubahan di dalam suatu organisasi, yakni ${ }^{15}$ :

a. Faktor eksternal: (1) karakteristik demografis, (2) perkembangan teknologi, (3) perubahan yang terjadi di pasar, (4) tekanan sosial dan politik.

b. Faktor internal: (1) masalah sumber daya manusia (kebutuhan yang tidak terpenuhi, kepuasan kinerja yang tak tercapai, produktifitas, motivasi kerja), (2) perilaku, dan (3) keputusan manajemen.

Menurut Cummings dan Worley, ${ }^{16}$ perubahan organisasi disebabkan oleh permasalahan atau munculnya ketidakwajaran yang menuntut organisasi untuk berubah. Sumber-sumber pemicu perubahan yakni:

\footnotetext{
13 Ibid.

${ }^{14}$ J. Winardi, Manajemen Perubahan (Management of Change) (Jakarta: Kencana Prenada Media, 2010), hlm. 86-87.

${ }^{15}$ Arbono Lasmahadi, 'Perubahan dalam Perusahaan Tantangan atau Ancaman', Jurnal Psikologi, Manajemen, Vol 2, Nomor 4, (2005), hlm. 4

${ }^{16}$ Erika Setyani Kusumaputri, Komitmen Pada Perubahan Organisasi: Perubahan Organisasi dalam Perspektif Islam dan Psikologi (Yogyakarta: Deepublish, 2015), hlm.1.
} 
a. Lingkungan. Perubahan lingkungan merupakan hal paling utama yang mempengaruhi perubahan organisasi. Yang termasuk di dalam faktor lingkungan antara lain faktor ekonomi, teknologi, politik, kebudayaan dan hukum.

b. Sasaran dan nilai. Pemicu perubahan juga berasal dari adanya pergeseran sasaran organisasi. Pada sebuah organisasi terdapat nilai yang dipegang organisasi dalam mewujudkan sasarannya, nilai yang berubah juga akan memicu perubahan sasaran.

c. Teknik. Teknik yang digunakan oleh perusahaan akan sangat mempengaruhi adanya perubahan di dalam organisasi. Perubahan teknik di dalam organisasi, selain menjadi proses perubahan organisasi, juga terdapat pada bentuk dan fungsi suatu produk ataupun jasa.

d. Struktur. Sistem struktur merupakan salah satu sumber lain adanya perubahan dalam suatu organisasi. Perubahan di dalam struktur ini meliputi perubahan sistem hingga ke subsistem di dalam organisasi.

e. Manajerial. Terdapat tahapan perencanaan hingga pengawasan di dalam sebuah organisasi. Manajerial menjadi penanggung jawab utama dalam setiap tahapan tersebut, oleh karenanya manajerial berfungsi menjaga keseimbangan organisasi dalm kondisi dinamis ditengah perubahan tuntutan adaptasi dan inovasi. ${ }^{17}$

\section{Tujuan Perubahan}

Stephen P. Robbins mengungkapkan tujuan perubahan yang terencana terdapat dua macam, yakni: (1) sebagai upaya organisasi dalam memperbaiki kemampuan organisasi dalam penyesuaian organisasi terhadap perubahan yang dinamis, (2) sebagai upaya dalam proses perubahan perilaku karyawan atau anggota organisasi. ${ }^{18}$

Tujuan perubahan dalam manajemen suatu lembaga tentu memiliki tujuan yang ingin dicapai. Berikut beberapa tujuan manajemen perubahan pada sebuah lembaga:

a. Untuk mempertahankan keberlangsungan hidup lembaga, baik itu dalam jangka pendek maupun jangka panjang.

b. Untuk menyesuaikan diri dengan perubahan yang berasal dari faktor internal lembaga (sikap tenaga kerja, perubahan strategi korporasi, perubahan teknologi dan peralatan dan lainnya), dan juga faktor eksternal (perubahan pasar, peraturan, hukum, kebijakan pemerintah, teknologi dan lainnya).

c. Untuk memperbaiki efektivitas lembaga agar dapat bersaing. Upaya ini termasuk perbaikan efektivitas tenaga kerja, perbaikan sistem dan struktur organisasi, dan implementasi strategi lembaga.

Jika kembali ke obyek penelitian penulis, yaitu Penelitian mengenai bagaimana pemimpin Pondok Pesantren Tegalsari mengadakan perubahan di lembaga yang dipimpinnya, tentu tujuan-tujuan perubahan manajemen di atas bisa dijadikan acuan oleh Pemimpin lembaga (Pengasuh Pondok Pesantren) tersebut.

\section{Model Perubahan Organisasi}

Anderson \& Anderson memberikan kesimpulan bahwa model-model perubahan organisasi menuju ke arah dua kategori, yaitu model kerangka (framework model) dan model proses (process model). Model proses perubahan adalah suatu proses utuh yang

\footnotetext{
${ }^{17}$ Siswanto dan Agus Sucipto, Teori dan Perilaku Organisasi: Sebuah Tinjauan Integratif (Malang: UIN Malang Press, 2008), hlm.105.

${ }^{18}$ Dadang Rahman Munandar, 'Manajemen Perubahan Organisasi Sekolah Luar Biasa'...., hlm.282.
} 
terdiri atas tiga macam situasi, yakni: upstream change (penyusunan dasar-dasar untuk kesuksesan), midstream change (rancangan), dan downstream change (implementasi). ${ }^{19}$

Sedangkan Grundy menjabarkan bahwa perubahan dapat dibagi ke dalam tiga jenis, antara lain ${ }^{20}$ :

\section{a. Smooth Incremental Change}

Perubahan disini terjadi secara lambat, terstruktur, dan juga dapat terprediksi arah perubahannya. Smooth Incremental Change terdiri atas sederetan perubahan yang terjadi pada kecepatan yang statis (konstan, tetap tidak berubah atau terusmenerus).

\section{b. Bumpy Incremental Change}

Pada Bumpy Incremental Change, perubahan yang terjadi memiliki ciri-ciri yakni, terjadi dalam keadaan yang relatif tenang meskipun sesekali muncul kecepatan perubahan meningkat. Pendorong adanya perubahan ini berlatarbelakang atas perubahan lingkungan lembaga, perubahan faktor internal seperti tuntutan peningkatan efisiensi kerja. Contohnya, reorganisasi yang secara periodik dilakukan oleh pondok pesantren.

c. Discontinuous Change

Pada Discontinuous Change, perubahan terjadi secara cepat dan signifikan dimulai dengan adanya pergerakan cepat pada strategi, budaya atau struktur, ataupun ketiganya secara bersamaan. Dalam situasi seperti ini, Discontinuous Change dapat diredam dengan perubahan sebagai respon atas pergeseran besar yang terjadi di lingkungan, berbagai kejadian dan kondisi tak terduga terbit lebih cepat bila dibandingkan dengan kemampuan organisasi untuk meresponnya.

\section{Model Perubahan Organisasi Pondok Pesantren Tegalsari}

Situasi pandemi Covid-19 memberi dampak yang luas dan relatif cepat. Dampakdampak tersebut diantarnya meliputi dampak harus berubahnya pola pendidikan di Pondok Pesantren Tegalsari. Berbahayanya Virus Covid-19 menuntut kewaspadaan tinggi oleh organisasi-organisasi pendidikan seperti Pondok Pesantren Tegalsari.

Atas situasi ini, maka Pemimpin atau Pengasuh Pondok Pesantren Tegalsari menggunakan model perubahan Discontinuous Change yakni perubahan terjadi secara cepat dan signifikan dimulai dengan adanya pergerakan cepat pada strategi, budaya atau struktur, ataupun ketiganya secara bersamaan. Dalam hal ini Discontinuous Change sebagai bentuk respon atas kejadian wabah pandemi covid-19 yang tiba-tiba muncul dan bergerak secara cepat.

\section{Strategi Perubahan Organisasi}

Thompson menjabarkan bahwa pengelolaan faktor lingkungan (nilai-nilai) sumber daya akan sangat berpengaruh pada keefektifan strategi perubahan yang dijalankan. Semakin besar kesinkronan dan kesesuaian (congruence) antara lingkungan (nilai-nilai) sumber daya, maka akan semakin besar kemungkinan organisasi tersebut dapat menjalankan pengelolaan sumber daya secara efektif. ${ }^{21}$

\footnotetext{
${ }^{19}$ Dean Anderson, Linda A. Anderson, Beyond Change Management: Advanced Strategies for Today's Transformational Leaders. (Jossey Bass: John Wiley \& Sons Inc, 2001).

${ }^{20}$ Uyung Sulaksana, Manajemen Perubahan (Yogyakarta: Pustaka Pelajar, 2004), hlm.35-37.

${ }^{21}$ Dadang Rahman Munandar, 'Manajemen Perubahan Organisasi Sekolah Luar Biasa'...., hlm.282.
} 
Terdapat beberapa macam pendekatan alternatif manajemen perubahan. Gibson memiliki pendapat bahwa terdapat 3 alternatif pendekatan manajemen perubahan dan pengembangan organisasi, yakni ${ }^{22}$ :

a. Kekuasaan (Power)

Penerapan kekuasaan dalam menuju perubahan yang ingin idcapai dilakukan dengan adanya unsur paksaan. Melalui kekuasaan yang dimiliki, pemimpin dapat menekan bawahannya untuk mengubah arah seperti yang dikehendaki pimpinan. Seorang pemimpin dapat mendukung terjadinya pengaruh yang positif di dalam organisasi, sehingga pemimpin akan memiliki sikap yang tegas pada perubahan dan pengembangan organisasi yang akan melibatkan setiap individu ataupun kelompok baik yang sependapat maupun tidak.

b. Alasan (Reason)

Pemimpin akan menggunakan alasan dalam perubahan. Alasan yang diberikan pemimpin dapat berupa alasan organisasi harus mengubah arah tujuannya dan alasan mengenai organisasi yang harus dikembangkan. Data dan penjelasan yang masuk akal sangat penting bagi personal dan kelompok yang berada di dalam organisasi agar terlibat secara aktif dalam perubahan dan pengembangan organisasi.

c. Pendidikan Kembali (Reducation)

Pendidikan kembali yang berfungsi sebagai perbaikan fungsi organisasi menjadi dasar pendekatan poros tengah "middle range approach". Pendidikan kembali memberikan dampak bahwa kekuasaan maupun alasan tidak membawa perubahan yang diinginkan.

\section{Peran Pengasuh Lembaga Pondok Pesantren Tegalasi dalam Manajemen Perubahan}

Imam Machali (2018) menjelaskan bahwa suatu organisasi atau perkumpulan dapat berjalan apabila terdapat seorang pemimpin di dalamnya. Pemimpin dalam suatu organisasi bertugas untuk membawa anggota organisasi bekerja bersama sesuai dengan tanggung jawabnya masing-masing serta organisasi dibawa kearah tujuan yang ingin dicapai bersama. Apabila dijabarkan secara lebih terperinci, tugas pemimpin organisasi adalah untuk mengawasi, membenarkan, meluruskan, memandu, menerjemahkan, menetralisasi, mengorganisasikan dan mentransformasikan kebutuhan serta harapan anggota yang ada dalam organisasi. ${ }^{23}$

Lembaga pendidikan Islam yang dipimpin oleh seorang Pengasuh atau Kyai, tentu saja membawa peranan penting dalam manajemen perubahan lembaga yang dipimpinnya. Setiap perubahan memerlukan agen perubahan, yakni agar dapat membantu organisasi atau lembaga pendidikan dalam perubahan tersebut. Perubahan dapat terjadi dan berjalan dengan baik dengan adanya kepala sekolah yang berperan sebagai pemimpin yang memiliki visi jelas, yaitu tentang gambaran sekolah yang dicita-citakan. Di samping itu, Pengasuh Pondok Pesantren Tegalsari juga harus mampu membimbing, mendorong, dan mengorganisasikan santri dan staf dengan baik. $^{24}$

\footnotetext{
${ }^{22}$ Abdul Aziz Wahab, Anatomi Organisasi dan Kepemimpinan: Telaah Terhadap Organisasi dan Pengelolaan Organisasi Pendidikan, (Bandung: Alfabeta, 2011), hlm.307-308.

${ }^{23}$ Imam Machali, Ara Hidayat, The Handbook of Education Management, (Jakarta: Prenadamedia, 2018) hlm 93

${ }^{24}$ Muchlas Samani dkk, Manajemen Sekolah: Panduan Praktis Pengelolaan Sekolah (Yogyakarta: Dewan Pendidikan Kota Yogyakarta, 2009), hlm.181-183.
} 

sebagai:

Pengasuh Pondok Pesantren Tegalsari sebagai agen perubahan, yaitu memiliki peran

1. Catalyst, memiliki peran dalam memberikan keyakinan kepada orang lain mengenai pentingnya perubahan menuju situasi yang lebih baik.

2. Solution givers, memiliki peran dalam memberikan ingatan akan tujuan akhir dari perubahan yang sedang dilakukan. Kondisi disini mendorong untuk memoertahankan tujuan akhir yang ingin dicapai, namun perubahan terjadi pada metode dan strategi lembaga.

3. Process helpers, memiliki peran dalam memberikan bantuan kelancaran proses perubahan, khususnya dalam penyelesaian masalah yang timbul dan membina hubungan baik antara berbagai macam pihak yang terkait.

4. Resource linkers, memiliki peran sebagai penghubung antara individu dengan individu lain yang memiliki sumber dana atau alat yang dibutuhkan.

\section{Kesimpulan}

Manajemen perubahan dalam paradigma organisasi, maka dapat ditarik kesimpulan bahwa manajemen perubahan adalah sebuah proses yang terstruktur mulai dari pembuatan rencana, pengorganisasian, pelaksanaan, hingga pengendalian yang dijalankan oleh pengurus organisasi guna mewujudkan pergeseran situasi dari masa sekarang ke situasi yang diinginkan di masa yang akan datang, dengan melibatkan sumber daya organisasi untuk mewujudkan tujuan yang telah dirancang bersama secara efektif dan efisien.

Schermerhorn, Hunt, Osborn mengungkapkan terdapat dua macam konsep perubahan yakni; (1) konsep perubahan yang terencana (Planned Change) dan (2) konsep perubahan yang tidak terencana (Unplanned Change). Faktor pendorong perubahan dapat dikategorikan ke dalam faktor eksternal dan internal. Menurut Cummings dan Worley, sumber-sumber pendorong perubahan yakni: lingkungan, sasaran dan nilai, teknik, struktur, dan manajerial. Tujuan perubahan terencana menurut Stephen P. Robbins ada dua, yaitu: (1) sebagai upaya organisasi dalam memperbaiki kemampuan organisasi dalam penyesuaian organisasi terhadap perubahan yang dinamis, (2) sebagai upaya dalam proses perubahan perilaku karyawan atau anggota organisasi. Gibson menjelaskan pendekatan manajemen perubahan yakni : power, reason, reducation.

Perubahan di Pondok Pesantren Tegalsari di tengah pandemic dapat terjadi dan berjalan dengan baik tidak lepas karena adanya Pengasuh yang berperan sebagai pemimpin yang memiliki visi jelas, yaitu tentang gambaran lembaga yang dicita-citakan. Di samping itu, Pengasuh Pondok Pesantren juga mampu membimbing, mendorong, dan mengorganisasikan para santri dan staf dengan baik. Peran Pengasuh, dengan demikian adalah sebagai catalyst, solution givers, process helpers, resources linkers.

\section{Saran}

Perubahan meupakan sebuah keharusan dalam setiap roda perjalanan kehidupan. Oleh karenanya hendaklah Pengasuh Pondok Pesantren sebagai pemangku kebijakan tertinggi pada lembaga pendidikan dapat beradaptasi dengan masa sulit karena pandemic seperti saat ini. Pengasuh Pondok Pesantren hendaknya memiliki fleksibelitas yang tinggi untuk dapat mencapai perubahan pada lembaga yang dipimpinnya. Apabila seorang Pengasuh masih bersikap kolot, maka manajemen perubahan tidak dapat dilaksanakan dan lembaga pendidikan yang dipimpinnya yang akan menjadi korbannya. 


\section{Daftar Pustaka}

Abdullah, M. Ma'ruf . Manajemen Berbasis Syariah. Yogyakarta: Aswaja Pressindo. 2012

Ahmad Ibrahim Abu Sinn. Manajemen Syariah. Jakarta: PT Raja Grafindo Persada. 2012.

Amirullah dan Rindyah Hanafi, Pengantar Manajemen. Malang: Graha Ilmu, 2002.

Anderson, Dean, Linda A. Anderson, Beyond Change Management: Advanced Strategies for Today's Transformational Leaders, Jossey Bass: John Wiley \& Sons Inc, 2001.

Daft, R. L. Management (2 nd .ed). Orlando: The Dryden Press a Division of holt Rinehart and Winston, Inc, 1991.

Davidson, Jeff, Change Management, The Complete Ideal's Duides, Jakarta: Prenada, 2005.

Depdikbud, Kamus Besar Bahasa Indonesia, Jakarta: Balai Pustaka, 1998.

Fahmi Khumaini, Rz., dan Ricky Satria Wiranata. Kepemimpinan Dalam Pendidikan Islam.Al-Fahim, Jurnal Manajemen Pendidikan Islam 01 (2). 2019.

Kementerian Tenaga Kerja dan Transmigrasi, Konsep Rencana Strategis Manajemen Perubahan Kementerian Tenaga Kerja dan Transmigrasi Republik Indonesia Tahun 2012, Jakarta: Kemnakertrans, 2012.

Kusumaputri, Erika Setyani. Komitmen Pada Perubahan Organisasi: Perubahan Organisasi dalam Perspektif Islam dan Psikologi. Yogyakarta: Deepublish, 2015.

Lasmahadi, Arbono, 'Perubahan dalam Perusahaan Tantangan atau Ancaman', Jurnal Psikologi, Manajemen, Vol 2, Nomor 4 (2005)

Lewin, K., Group Decision and Social Change. Readings in Social Psychology, London: Methuen and Co LTD, 1951.

Machali, Imam, Ara Hidayat. 2018. "The Handbook of Education Management". Jakarta: Prenadamedia

Muchlas Samani dkk. Manajemen Sekolah: Panduan Praktis Pengelolaan Sekolah. Yogyakarta: Dewan Pendidikan Kota Yogyakarta, 2009.

Munandar, Dadang Rahman, 'Manajemen Perubahan Organisasi Sekolah Luar Biasa', Jurnal Wahana Karya Ilmiah, Vol. 3, Nomor 1 (2019).

Potts, Rebecca and La Marsh, Jeanne, Managing for Success, London: Duncan Baird Publishers, 2004

Rue, Leslie W. \& Byars Lloyd L. Human Resources Management. Boston: Irwin, 2000.

Siswanto dan Agus Sucipto. Teori dan Perilaku Organisasi: Sebuah Tinjauan Integratif. Malang: UIN-Malang Press, 2008.

Sulaksana, Uyung. Manajemen Perubahan. Yogyakarta: Pustaka Pelajar, 2004.

Wahab, Abdul, Umiarso. Kepemimpinan Pendidikan dan Kecerdasan Spiritual, Yogyakarta: Ar-Ruzz Media. 2011

Wahab, Abdul Aziz. Anatomi Organisasi dan Kepemimpinan Pendidikan: Telaah terhadap Organisasi dan Pengelolaan Organisasi Pendidikan. Bandung: Alfabeta, 2011.

Wibowo, Managing Change, Pengantar Manajemen Perubahan, Pemahaman Tentang Mengelola Perubahan dalam Manajemen, Bandung: ALFABETA, 2006

Winardi, J. Manajemen Perubahan (Management of Change). Jakarta: Kencana Prenada Media, 2010. 